\title{
Sustainable Environmental Manufacturing Practice (SEMP) and Firm Performance: Moderating Role of Environmental Regulation
}

\author{
Hameed O. Adebambo ${ }^{1}$, Hasbullah Ashari ${ }^{1} \&$ Norani Nordin ${ }^{1}$ \\ ${ }^{1}$ School of Technology Management \& Logistics, University Utara Malaysia, Sintok-Kedah, Malaysia \\ Correspondence: Hameed O. Adebambo, School of Technology Management \& Logistics, Universiti Utara \\ Malaysia, 06010 Sintok-Kedah Darul Aman, Malaysia. Tel: 60-16-466-5548. E-mail: segham003@yahoo.com
}

Received: September 25, $2014 \quad$ Accepted: October 10, 2014 Online Published: November 26, 2014

doi:10.5539/jms.v4n4p167ＵRL: http://dx.doi.org/10.5539/jms.v4n4p167

\begin{abstract}
Theoretical evidence shows that a considerable amount of attention has been given to environmental issues in academic researches in the past years and the link between sustainable environmental practices and firm performance remains inconclusive. One of the reasons for this inconsistent relationship is due to the increasing regulatory requirements of the environmental sustainable practices which have become increasingly stringent on yearly basis. This study investigates the moderating effect of environmental regulation on the relationship between sustainable environmental manufacturing practices and firm performance. Data was collected by using a mail survey questionnaire from the manufacturing companies in Malaysia and analyzed with PLS-SEM. The result of the empirical investigation found that environmental regulation only moderates the relationship between SEMP and environmental performance. The relationships between SEMP; and financial and operational performance were not significantly moderated by stringent environmental regulation. The study recommends that environmental policy makers should revisit the blueprint about environmental regulation on environmental practices to provide supportive environmental policies that will enhance a better financial and operational performance in manufacturing industry.
\end{abstract}

Keywords: sustainable environmental manufacturing practices, firm performance, environmental regulation

\section{Introduction}

Traditionally, association exists between manufacturing firms and the undesirable environmental impacts (Frosch \& Gallopoulos, 1989; Despeisse, Ball, \& Evans, 2012). Environmental problem has been linked to the operational activities of manufacturing firms as economic values are produced by manufacturing firms in transforming resources input into useful output under the guidance of environmental regulation (Gutowski, Branham, Dahmus, Jones, Thiriez, \&Sekulic, 2009). As such, environmental practice has become a vital global issue that creates challenges for the society and manufacturing practitioners (Jovane, Yoshikawa, AltingBoër, Westkämper, Williams, Tseng, Seliger, \& Paci 2008).

The report of the International Environmental Agency (2007) revealed that manufacturing industries are significantly responsible for the consumption of a huge amount of resources and waste generation throughout the world. This is evidenced in the obvious increase of $61 \%$ in the consumption of energy by manufacturing industries between 1972 and 2004, they are also responsible for about a third of the world's global usage of energy and emission of $36 \%$ of carbon dioxide $\left(\mathrm{CO}_{2}\right)$ in the world (Organization for Economic Corporation Development, 2009). In Malaysia, manufacturing sector is responsible for a portion of the environmental degradation. This is witnessed in the increasing volume of generated waste of stationary source from industries(Department of Environment, 2012; Environmental Statistics Time Series, 2012).

Malaysia has been dealing with the issues of environmental degradation caused by the activities of manufacturing firms to achieve economic growth which has resulted into environmental pollution (Department of Environment, 2012; Environmental Statistics Time Series, 2012). Thus, there requires the need to strike a balance between the environmental and developmental issues in order to ensure that the economic benefits are not negated by the cost of environmental changes which has long been recognized by Malaysia through enactments of law, policies, regulations (DOE, 2012; ESTS, 2012). Therefore, there is a need to ensure that manufacturing firms embark on sustainable environmental practices to minimize their environmental impacts and ensure that resources are conserved. 
Theoretical evidence from previous studies show that a considerable amount of attention has been given to environmental issues in academic researches in the past years and the link between environmental practices and performance of firms has been widely discussed which results into different views (Nyirenda et al., 2013; Clarkson, et al., 2011; Barnet, 2007; Cho \& Patten, 2007; Ahmed et al., 1998; Ahmed et al., 2003). One of the debated points of view is that the implementation of sustainable environmental manufacturing practices is integral to the performance of manufacturing companies as it provides a long-term economic gain to companies (Ahmed et al., 1998; Ahmed et al., 2003; Hartmut \& Kara, 2006; Hart, 1995; Clarkson et al., 2008, 2011) by inducing cost savings and increasing sales. Another engaging view of environmental sustainable practices is that it is a mere investment on practices that increase the cost of manufacturing companies as firms incur extra cost while implementing this environmentally friendly practices (Cho \& Patten, 2007; Judge \& Krishman, 1994; Walley \& Whitehead, 1994; Freeman, 1994) and thus, reduces firms' profitability, while some studies found that there is no existing relationship between the two concepts (Watson et al., 2004; Link \& Naveh, 2006; Ullman, 1985). Thus, the relationship between sustainable environmental practices and firm performance remains inconclusive (Schoenherr \& Talluri, 2012; Arafat, Warokka, \& Dewi, 2012; Lopez-Gamero, Molina-Azorin, \& Claver-Cortes, 2009). To clarify this inconclusive assertion in previous studies, an empirical study is needed for further investigation in this domain.

The inconsistent results of previous studies could be as a result of the regulatory requirements of the environmental sustainable practices which have become increasingly stringent on a yearly basis (Hartmut \& Kara, 2006) as environmental regulation was put in place to control the impact of industrial activities in order to promote a sound environment and sustainable development (DOE, 2010). Thus, it provides the need for firms to implement sustainable environmental practices. However, the motives of firms in implementing sustainable environmental practices are either to avoid sanctions and punishments in the form of penalties, fines or withdrawal of license as a result of non-compliance with environmental regulations (Lai \& Wong, 2012; Davidson \& Worreli, 2001). In this case, if environmental regulation is low, firms implement environmental initiative just to satisfy the basic requirement of the regulation which will not pay off on performance achievement. However, in the wake of a more stringent environmental regulation, the needs to comply with the regulation increases and which intensify the dedication and implementation of sustainable environmental practices by manufacturing firms which signaled an achievement of better firm performance. Lai and Wong (2012) found that a more stringent regulatory pressure enhances the green logistic management and firm performance relationship. Therefore, this study argues that more stringent environmental regulation will enhance the relationship between SEMP and firm performance.

\section{Literature Review}

\subsection{Sustainable Environmental Manufacturing Practice (SEMP) and Firm Performance}

The natural resources based view (NRBV) theory of firm (Hart, 1995) posits that organizational activities that incorporate environmentally sustainable practices can lead to competitive advantage and thus better firm performance. A better evaluation of the relationship between firms' sustainable environmental manufacturing practices (SEMP) and performance is provided by the NRBV through its emphasis on the link between the firms' resources, capabilities and the strategic management results of the firms' actions. The theory regards the natural environment within which firm operates as a resource that can be strategically used to achieve better performance. The emphasis of NRBV has enhanced researchers to identify the link between firms' sustainable environmental practices and performance.

The outcomes of sustainable environmental manufacturing practices have previously been examined (Ameer \& Othman, 2011; Lopez-Gamero et al., 2009; Chen \& Shih, 2007; Wagner, 2005; Zhu \& Sarkis, 2004). Ameer \& Othman (2011) and Chen \& Shih (2007) found a positive relationship between environmental practices and financial performance of firms. Lopez-Gamero et al. (2009) on the relationship between environmental variables and firm performance affirmed that proactive environmental practice is significantly related to firm performance. Chin \& Shih (2007) in their investigation on green manufacturing practices among the Chinese industries established that green manufacturing practice is positively related to the financial performance. Furthermore, Hart \& Ahuja (1996) confirmed that a significant relationship exists between reducing emission and operating and financial performance. As a result, this study posited a positive relationship between the SEMP and firm performance.

In a similar vein, previous studies such as Schoenherr and Talluri (2012) found a positive relationship between sustainable environmental practices and plant efficiency while Lai and Wong (2012) affirmed a positive relationship between environmental management and operational performance in green logistics. The positive 
relationship between environmental practices and operational performance was also confirmed by a case study by Tooru (2001).

It is generally believed that a trade-off exists between environmental proactiveness and firm's productivity (Porter \& Van der Linde, 1995). The pursuit of environmental goals is usually associated with increased cost at the beginning of the implementation of sustainable environmental manufacturing practices; however, it results into benefits such as cost savings and better financial performance in the long run (King \& Lenox, 2001). The concept of SEMP is directed towards environmental practices such as reduction of energy consumption, carbon emission reduction and waste minimization which lessen environmental degradation caused by manufacturing industries and thus improve firm's environmental performance. Zhu and Sarkis (2004) affirmed that there is a direct positive relationship between internal environmental practices and environmental performance.

Based on the above discussion, this study posits the following hypotheses between the implementation of SEMP and firm performance:

H1a: Sustainable environmental manufacturing practices will positively influence financial performance.

H1b: sustainable environmental manufacturing practices will positively influence operational performance.

H1c: Sustainable environmental manufacturing practices will positively influence environmental performance.

\subsection{Moderating Role of Environmental Regulation on SEMP and Firm Performance}

Environmental regulations are enacted to control the environmental damages caused by the operations of firms therefore, manufacturing firms are mandated to operate under the requirements of the regulation (Lai \& Wong, 2012). The traditional view of environmental regulation on performance of firms is that environmental regulation comes with additional cost that erodes the profits of the firm. However, if environmental regulation is well designed and properly channeled, it has a tendency to offset the cost of compliance and strives innovation which results into environmental and business performance (Porter \& Van der Linde, 1995; 1998).

Environmental regulation strengthens the implementation of SEMP in manufacturing firms by providing environmental standards and requirements on environmental conformances. Therefore, there is a need for environmental regulation compliances to strengthen the dedication of the manufacturing firm on the implementation of SEMP. This assertion was corroborated by the result of Lai and Wong (2012) on green logistic management among the Chinese manufacturing exporter which found that environmental regulation moderates the relationship between the environmental practices and firm performance.

Environmental regulation provides the need for firms to implement SEMP while the requirements of regulation guide the practices of manufacturing firms to preserve the environment. In order for a firm to gain more competence in an environment with stringent environmental regulation, SEMP is required to offset the unproductive cost of non-compliance. In view of a stringent environmental regulations and requirements, SEMP is required to boost the financial, environmental and operational performance of manufacturing firms. This assertion was supported in the empirical findings of Lai and Wong (2012) which found environmental performance as a moderator on the relationship between Green Logistic Management and firm performance.

Based on the above discussion, the following moderating effect hypotheses of environmental regulation are posited between SEMP and firm performance:

H2a: Stringent environmental regulation will moderate the relationship between SEMP and financial performance.

H2b: Stringent environmental regulation will moderate the relationship between SEMP and operational performance.

H2c: Stringent environmental regulation will moderate the relationship between SEMP and environmental performance.

\section{Methodology}

\subsection{Population and Sampling}

The population of this study is the manufacturing companies that are registered in Malaysia with more than 50 full-times employees. These companies are regarded as technically and financially feasible for implementing sustainable environmental manufacturing practices. Sample of this study was selected from the directory of the Federation of Malaysian Manufacturer (FMM, 2013) by using a simple random sampling technique. Data were collected from the operation, manufacturing manager or the environmental, health and safety manager of the selected sample company by using a mail-survey questionnaire. This study distributed 790 questionnaires out of 
which 103 usable questionnaires were returned and used for the main analysis. The received questionnaire represents $13 \%$ response rate which is similar to the $12 \%$ obtained by Wong et al., (2011) and $11.5 \%$ response rate by Ahmed and Hassan (2003) in the context of Malaysia. As a result, the 13\% response rate in this study is considered reasonable.

\subsection{Instrumentation}

Items of the questionnaire used were adapted from previous literatures similar to this study. All the items were measured on a scale of 1- 6 in which " 1 " indicates strongly disagree and "6" indicates strongly agree. Specifically, items used in measuring sustainable environmental manufacturing practices were adapted from Gonzalez-Benito \& Gonzalez-Benito (2006), items for financial performance were adapted from Henri \& Journeault (2008), items for operational and environmental performance were adapted from Lai \& Wong (2012), while items for environmental regulation were adapted from Lai and Wong (2012) and Carter et al. (2009).

\subsection{Data Analysis Techniques}

This study used both SPSS version 20 and PLS-SEM 2.0 M3 (Ringle et al., 2005) to analyze the data collected. The preliminary analysis, such as the detection and treatment of missing data, outliers and linearity assumption was done with SPSS. While PLS-SEM was used based on the reasons that it offers several advantages in predicting significant relationship with small sample size, types of variables used, model complexity and place minimum requirement on data normality. Hence, PLS analysis technique was used for the assessment of the measurement and structural model in this study.

\section{Findings}

The demographic representation of the respondents of this study shows that electrical, electronics and computing machinery sector $(50.5 \%)$ of manufacturing is the largest proportion of the respondents' companies, many of which occupy the environmental, health \& safety managers (50.5\%) position from the multinational companies (45.6\%) with their companies having more than 251 full-time employees. The estimation of the parameters of both the outer and the inner model in order to maximize the variance explained in the dependent variable by the independent variable was based on SmartPLS 2.0 M3 (Ringle et al., 2005) in assessing the model. The non-parametric bootstrapping method with 5000 resampling was used to obtain the standard errors of the estimates (Chin, 1998; Tenenhaus et al., 2005; Wetzel et al., 2009).

\subsection{Assessment of the Measurement Model}

The statistical result of the analysis shows that the loadings for all items in this study exceed the 0.5 threshold recommended by Hair et al., (2013). Concerning the composite reliability, the result indicates values ranging between 0.856 and 0.924 exceeding the threshold value of 0.7 (Hair et al., 2013). Furthermore, the average variance extracted (AVE) by the latent constructs provided values exceeding the threshold (0.5) ranging between 0.548 and 0.708 (Hair et al., 2013). Based on the statistical results of the loadings, AVE and the composite reliability, it was evidenced in this study that convergence validity was achieved. Thus, indicating the achievement of the goodness of fit (GoF) measure. Table 1 below presents the result of the items loading, composite reliability and AVE.

Table 1. The Loadings, AVE and Composite Reliability Analysis

\begin{tabular}{|c|c|c|c|c|}
\hline Constructs & Items & Loadings & AVE & CR \\
\hline \multirow[t]{6}{*}{ Environmental Performance } & - $\quad$ Reduced carbon emission & 0.783 & 0.668 & 0.909 \\
\hline & - $\quad$ Reduced waste water & 0.862 & & \\
\hline & - $\quad$ Reduced solid wastes & 0.821 & & \\
\hline & - Decreased the consumption of hazardous & 0.842 & & \\
\hline & material & & & \\
\hline & $\begin{array}{l}\text { - Decreased the frequency of environmental } \\
\text { accidents }\end{array}$ & 0.775 & & \\
\hline \multirow[t]{4}{*}{ Environmental Regulation } & $\begin{array}{l}\text { Environmental regulation enforcement } \\
\text { improves SEMP in our company }\end{array}$ & 0.804 & 0.602 & 0.856 \\
\hline & $\begin{array}{l}\text { - Environmental regulation is the major reason } \\
\text { why we practice SEMP }\end{array}$ & 0.873 & & \\
\hline & $\begin{array}{l}\text { Environmental regulation improves the growth } \\
\text { of our company }\end{array}$ & 0.772 & & \\
\hline & $\begin{array}{l}\text { Environmental regulation can be improved by } \\
\text { the environmental efforts of our company }\end{array}$ & 0.633 & & \\
\hline
\end{tabular}




\begin{tabular}{|c|c|c|c|c|}
\hline \multirow[t]{5}{*}{ Financial Performance } & - Increase in return on investment & 0.862 & 0.708 & 0.924 \\
\hline & - $\quad$ Increase in operating profit & 0.805 & & \\
\hline & - Increase in cash flow & 0.857 & & \\
\hline & - Increase in turnover rate & 0.804 & & \\
\hline & Increase in market share & 0.878 & & \\
\hline \multirow[t]{6}{*}{ Operational Performance } & - $\quad$ Improvement in production quality & 0.788 & 0.635 & 0.913 \\
\hline & - $\quad$ Lead time reduction & 0.759 & & \\
\hline & $\begin{array}{l}\text { - Improvement in the development of better } \\
\text { product }\end{array}$ & 0.845 & & \\
\hline & - $\quad$ Reduction in production waste & 0.786 & & \\
\hline & - $\quad$ Reduction in rejection rate of products & 0.795 & & \\
\hline & Increase in customer satisfaction & 0.806 & & \\
\hline \multirow{10}{*}{$\begin{array}{l}\text { Sustainable Environmental } \\
\text { Manufacturing Practices }\end{array}$} & - $\quad$ provides periodic elaboration of environmental & 0.725 & 0.548 & 0.906 \\
\hline & reports & & & \\
\hline & - trains employees on environmental issues & 0.767 & & \\
\hline & $\begin{array}{l}\text { - considers environmental issues in selecting } \\
\text { production process }\end{array}$ & 0.761 & & \\
\hline & - $\quad$ chooses suppliers based on environmental & 0.707 & & \\
\hline & issues & & & \\
\hline & $\begin{array}{l}\text { - Prevents pollution from the start of production } \\
\text { process }\end{array}$ & 0.809 & & \\
\hline & $\begin{array}{l}\text { - prevents wastes from the start of production } \\
\text { process }\end{array}$ & 0.705 & & \\
\hline & $\begin{array}{l}\text { - prevents air emission from the start of } \\
\text { production process }\end{array}$ & 0.733 & & \\
\hline & $\begin{array}{l}\text { - reduces energy use by better maintenance } \\
\text { procedure }\end{array}$ & 0.710 & & \\
\hline
\end{tabular}

Note. Composite reliability $(\mathrm{CR})=$ Square of the summation of the factor loadings $) /$ ( (square of the summation of the factor loadings $)+$ (square of the error variances) $\}$. Average variances extracted (AVE) $=$ (summation of the square of the factor loadings) $/\{($ summation of the square of the factor loadings) + (summation of the error variances) $\}$

\subsection{Discriminant Validity of the Constructs}

Discriminant validity explains whether the concept presented by a construct is unique and not represented by another construct in the model (Hair et al., 2013). It was evaluated in this study through the Fornel-Larcker criterion by comparing the square root of the AVE values with latent variable correlations (Fornell \& Larcker, 1981). Discriminant validity is evidenced when the squared root of each constructs' AVE is greater than its highest correlation with any other construct within the model (Hair et al., 2013). In this study, discriminant validity is achieved as shown in Table 2 below indicating the squared correlations for each construct as lesser than the average variance extracted by the indicators measuring that construct.

Table 2. Discriminant validity

\begin{tabular}{llllll}
\hline Constructs & EP & ER & FP & OP & SEMP \\
\hline EP & $\mathbf{0 . 8 1 7}$ & & & & \\
ER & 0.342 & $\mathbf{0 . 7 7 6}$ & & & \\
FP & 0.361 & 0.292 & $\mathbf{0 . 8 4 2}$ & $\mathbf{0 . 7 9 7}$ & \\
OP & 0.511 & 0.428 & 0.666 & 0.360 & $\mathbf{0 . 7 4 0}$ \\
SEMP & 0.421 & 0.526 & 0.283 & \\
\hline
\end{tabular}

Note. Values in the diagonals represent the squared root of the average variance extracted while the other entries (off diagonals) represent the variable correlations.

\subsection{Assessment of Structural Model}

\subsubsection{SEMP and Firm Performance}

The formulated hypotheses were tested through the assessment of the structural model of this study. As depicted by Table 3 which revealed the result of the standard path coefficients $(\beta)$, standard error, t-value and the decision taken in this study. It was found that only one of the three (3) hypotheses was significant; between SEMP and 
environmental performance (EP) $(\beta=0.264, \mathrm{t}=2.336, \mathrm{P}<0.10)$. While the remaining two hypotheses: SEMP and financial performance (FP) $(\beta=0.95, \mathrm{t}=0.715, \mathrm{P}<0.10)$; and (2) SEMP and operational performance (OP) ( $\beta=0.040, t=0.346, P<0.10)$ do not show any evidence of a significant relationship.

\subsubsection{Moderating Effect of Environmental Regulation between SEMP and Firm Performance}

The simple effect (SEMP -> FP) has a standardized beta $(\beta)$ value of 0.062 , the standardized beta $(\beta)$ value for ER -> FP is 0.128 while the -0.317 represents the standardized beta $(\beta)$ value for the moderation effect. The significance of the interaction model was assessed by using a bootstrapped sample size of 2000 and the result presented a t-value of 0.467 at $\mathrm{P}<0.10$ significant level between SEMP and financial performance. This result does not find a support that environmental regulation (ER) moderates the relationship between sustainable environmental manufacturing practices (SEMP) and financial performance (FP). Hence, hypothesis H1a is not supported. Also, a standardized beta ( $\beta$ ) value of 0.010 between SEMP and OP, 0.158 from ER to OP and the standardized beta $(\beta)$ value for the interaction effect is 0.259 with $\mathrm{R}^{2}$ value of 0.467 . The significance of the interaction of bootstrapped sample size of 2000 reveals a $t$-value of 0.972 indicating no moderating effect of Environmental regulation between SEMP and operational performance. In addition, a standardized beta Value ( $\beta$ ) for the simple effect (SEMP -> EP) is 0.236, standardized beta $(\beta)$ value of 0.105 was found for ER -> EP while the interaction effect (SEMP * ER -> EP) has a standardized beta $(\beta)$ value of 0.239 and the $\mathrm{R}^{2}$ value was found to be 0.311 . The $t$-value was found to be 2.253 at $\mathrm{P}<0.10$ which provide an evidence to support that environmental regulation (ER) moderates the relationship between SEMP and environmental performance. Table 3 below presents the summary of the hypotheses testing in this study.

Table 3. Results for the direct hypotheses

\begin{tabular}{llllll}
\hline Hypotheses & Path coefficient & Beta & Std. Error & T-Value & Decision \\
\hline H1a & SEMP -> FP & 0.095 & 0.133 & 0.715 & Not Supported \\
H1b & SEMP - > OP & 0.040 & 0.115 & 0.346 & Not Supported \\
H1c & SEMP - EP & $0.264^{*}$ & 0.113 & 2.336 & Supported \\
H2a & SEMP * ER -> FP & -0.317 & 0.347 & 0.912 & Not Supported \\
H2b & SEMP * ER -> OP & 0.259 & 0.266 & 0.972 & Not supported \\
H2c & SEMP * ER - EP & $0.239 *$ & 0.106 & 2.253 & Supported \\
\hline
\end{tabular}

Note. $* \mathrm{P}<0.10$, Indicates the item is significant at $10 \%$ significant level.

\subsubsection{Effect Size $\left(\mathrm{F}^{2}\right)$}

The effect size $\mathrm{f}^{2}$ is the extent to which the examined path changes the explaining power of the endogenous construct (Cohen, 1988). In determining the effect size, Cohen $\mathrm{F}^{2}$ value was used and calculated with the formula provided below by Cohen (1988):

$$
\mathrm{F}^{2}=\frac{\mathrm{R}_{\text {included }}^{2}-\mathrm{R}_{\text {excluded }}^{2}}{\mathrm{R}_{\text {included }}^{2}}
$$

Based on the guidelines provided by Cohen (1988), $\mathrm{f}^{2}$ values of $0.02,0.15$ and 0.35 respectively represent small, medium and large effect of the exogenous constructs on the endogenous constructs. Chen et al., (2003) provided that those relationships with small effect sizes are as well important statistically with the other medium effect size as all effect sizes have their own peculiarity in influencing the dependent variable and therefore should be considered. The effect size is shown in Table 4 below.

Table 4. Effect size of the hypothesized relationships

\begin{tabular}{lllll}
\hline Relationship & $\begin{array}{l}\mathbf{R}^{\mathbf{2}} \\
\text { Included }\end{array}$ & $\mathbf{R}^{\mathbf{2}}$ Excluded & Effect Size $\left(\mathbf{F}^{\mathbf{2}}\right)$ & Rating \\
\hline SEMP -> FP & 0.143 & 0.139 & 0.005 & None \\
SEMP -> OP & 0.314 & 0.313 & 0.001 & None \\
SEMP-> EP & 0.220 & 0.178 & 0.054 & Small \\
SEMP * ER -> FP & 0.270 & 0.197 & 0.10 & Small \\
SEMP * ER -> OP & 0.467 & 0.399 & 0.128 & Small \\
SEMP * ER -> EP & 0.311 & 0.285 & 0.038 & Small \\
\hline
\end{tabular}




\subsubsection{Predictive Relevance $\left(\mathrm{Q}^{2}\right)$}

The extracted cross validated result determines the predictability of the endogenous constructs and thus, reveals the model quality. Hair et al., (2013) affirmed that $\mathrm{Q}^{2}>0$ in a reflective endogenous variable indicates the model predictive relevance while a value of $\mathrm{Q}^{2}<0$ indicates the lack of predictive capability of the model. Therefore, it can be concluded in Table 5 that the model has a good predictive relevance.

Table 5. Construct Crossvalidated redundancy value

\begin{tabular}{llll}
\hline Total & SSO & SSE & 1-SSE/SSO \\
\hline EP & 515 & 447.491 & 0.131 \\
FP & 515 & 467.247 & 0.093 \\
OP & 618 & 499.383 & 0.192 \\
SEMP & 824 & 665.709 & 0.192 \\
\hline
\end{tabular}

Note. SSO-Sum of square of Observations; SSE - Sum of Squares of Prediction

Errors; while $Q^{2}$ value $=1-S S E / S S O$.

\section{Discussion}

Ecological system is destroyed when firms operate without showing regards to the natural resources as firms are charged with the responsibility of protecting the socio-environmental system upon which they rest. Firm's stakeholders (i.e., customers and society) at large are more aware of the negative impacts of business on the environment, thus, they require cleaner and more ethical activities as it cannot keep endlessly extracting resources without consequence (Vijayaraghavan, 2010). Resources like air, water, biodiversity, fossil fuels are the very building blocks upon which a successful business is built. With the rapid depletion of these essentials, business needs to learn to deal with the ominous constraint of environmental degradation.

Business organizations today need to implement sustainable environmental practices in order to survive, as social responsibility is not only on their environmental values but also on the economic success and performance of their organizations (Henri \& Journeault, 2008). Thus, sustainable environmental manufacturing practices may be regarded as a primary source of better firm performance of many firms (Anis \& Nurul, 2010; Seidel, Shahbazpour \& Siedel, 2007)

Though, hypotheses 1a and $1 \mathrm{~b}$ found positive relationships between SEMP with financial performance and operational performance, but the relationships were not found to be significant. This result is in contraryto the study of Lopez-Gamero et al. (2009); Ameer \& Othman (2011) and Lai \& Wong (2012) respectively. One plausible explanation for these insignificant relationships is the stage of the extent of implementation of SEMP in Malaysia. Omar \& Samuel (2011) revealed that the implementation of sustainable environmental initiatives in Malaysia regardless of the type of ownership is at a stage where environmental practices are only seen as ethical. At this stage, Malaysian manufacturing firms only perceive sustainable environmental practices as ethical; necessary things are only put in place as a reaction to pressure from high environmental regulation without giving adequate consideration to SEMP as a strategic factor to achieving better financial and operational performance (Molina-Azorin et al., 2009). Jabbour \& Santos (2006) assert that this stage of implementation only witnesses the incorporation of certain objectives of the company by the environmental management. Although the environmental variables might have been utilized by the firms in some certain aspects of production and processes, but it is yet to be considered as relevant as a strategic factor of the entire division of the firms (Molina-Azorin et al., 2009). The insignificant relationship between SEMP and financial performance may be backed up by the findings of Nishitani et al. (2013) who affirmed that only firms that voluntarily implement environmental practices will be significant in its financial performance. It was explained that only environmental performance is improved when firm implement environmental practices as a result of mandatory pressure, especially from environmental regulation, however, financial performance and operational performance is experienced in a voluntary environmental initiative.

Hypothesis $1 \mathrm{c}$ which posited that sustainable environmental manufacturing practices would positively influence environmental performance was supported by the findings of this study. This is similar to the previous study of Lai \& Wong (2012); Zhu \& Sarkis (2004). The implication of this finding reveals that improvement in sustainable environmental manufacturing practices in firms enables the achievement of the firms' environmental objectives like reduction of energy consumption in firms, reduced carbon emission and environmental degradation caused by the manufacturing activities of the firms. As such, the more firms are committed to SEMP, the better their achievement of environmental performance. 
Hypotheses $2 \mathrm{a}$ which posited that high environmental regulation would moderate the relationship between sustainable environmental manufacturing practices and firm performance is supported. The result is consistent with the findings of Lai \& Wong (2012) who asserted that high environmental regulation moderates the relationship between green logistics management and environmental performance in China. It implies that one standard deviation increase in environmental regulation will not only impact SEMP but will also increase the impact of SEMP on environmental performance, indicating that SEMP will result into a better environmental performance upon the increase in the stringency of environmental regulation. However, environmental performance will drop when environmental regulation is relaxed.

H2a which posited that environmental regulation (ER) would moderate the relationship between SEMP and financial performance (FP) was not supported. This result is not really a surprise as it is emphasized by Gray and Shadbegian (2010) that environmental abatement effort is associated with productivity reduction. Also, Rassier and Earnhart (2010) asserted that tighter regulation meaningfully lower firms' profitability. Furthermore, it was reiterated by the traditional economic literatures that stringent environmental regulation such as environmental taxes, technological standards and trade permits are regarded by the traditional economists as eroding firms of their benefits (Ambec et al., 2013).

Concerning hypothesis $\mathrm{H} 2 \mathrm{~b}$ which did not support that environmental regulation (ER) would moderate the relationship between (SEMP) and operational performance (OP). One plausible explanation for this finding relates to the view of the traditional economists and managers who regard environmental regulation as eroding firms of their profit (Ambec et al., 2013). This implies that firms spend more time and resources in meeting up with the technological operational standards which reflectively reduces operational performance of firms.

\section{Conclusion}

This study has provided several implications both in theory and practical by revealing the established linkage between sustainable environmental manufacturing practice and firm performance via the moderating influence of environmental regulation. It has revealed the current situation of sustainable environmental manufacturing practices in developing countries. Hence, it has enhanced the understanding of the scenario and current level of implementation of SEMP in manufacturing firms in developing countries, onto the effect of SEMP when it is not being considered as strategic factor that can enhance the achievement of better performance of firms.

The result of the empirical investigation found that environmental regulation only moderates the relationship between SEMP and environmental performance. The relationships between SEMP; and financial and operational performance were not moderated by stringent environmental regulation. However, if environmental regulation is well designed and properly channeled, it has a tendency to yield better environmental and business performance (Porter \& Vander Linde, 1995; 1998). As such, it is recommended that environmental policy makers and the concerned authorities on environmental issues such as the Department of Environment (DOE) revisits the blueprint about environmental regulation on SEMP to provide supportive environmental policies that will enhance a better firm financial and operational performance in manufacturing industry.

This research did not include respondents from the governmental sector, particularly, the environmental policy maker. As a result, the perception from only manufacturing firms' practitioners was considered. However, a sort of balance may be attained if the view of the environmental policy makers were included. Therefore, future researchers are implored to extend this study by including the perception of the environmental policy makers.

\section{References}

Ahmed, N. U., Motagno, R. V., \& Firenze, R. J. (1998). Organizational performance and environmental consciousness: An empirical study. Management Decision, 36(2), 57-62. http://dx.doi.org/10.1108/00251749810204124

Ahmed, N., Naffziger, D. W., \& Montagno, R. V. (2002). Perception of environmental consciousness in U.S. small business. Retrieved from http://iceb.nccu.edu.tw/proceedings/APDSI/2002/papers/paper43.pdf

Ahmed, S., \& Hassan, M. (2003). Survey and case investigation on application of quality management tools and techniques in SMIs. International Journal of Quality and Reliability $\quad$ Management, $\quad 20, \quad 795-826$. http://dx.doi.org/10.1108/02656710310491221

Al-Amin, S, C., Huda, N., \& Hamid, A. (2009). Trade, economic development and environment: Malaysian experience. The Bangladesh Development Studies, 32(3), 19-39.

Ambec, S., Cohen, M. A., Elgie, S., \& Lanoie, P. (2013). The Porter hypothesis at 20. Can environmental regulation enhance innovation and competitiveness? Review of Environmental Economics and Policy 
Advance Access, 0(0), 1-22.

Ameer, R., \& Othman, R. (2011). Sustainability practices and corporate financial performance: A study based on the top global corporations. Journal of Business Ethics.

Amrina, E., \& Yusof, S. M. (2011). Key performance indicators for sustainable manufacturing evaluation in automotive companies. Industrial Engineering and Engineering Management (IEEE), 2011 IEEE International Conference, 1093-1097. http://dx.doi.org/10.1109/IEEM.2011.6118084

Anis, F. M., \& Nurul, F. H. (2012). The development of sustainable manufacturing practices and sustainable performance in Malaysian automotive industry. Journal of Economics and Sustainable Development, 3(7).

Arafat, M. Y., Warokka, A., \& Dewi, S. R. (2012). Does environmental performance really matter? A lesson from the debate of environmental disclosure and firm performance. Journal of Organizational Management Studies.

Bansal, P. (2005). Evolving sustainably: A longitudinal study of corporate sustainable development. Strategic Management Journal, 26(3), 197-218. http://dx.doi.org/10.1002/smj.441

Bansal, P., \& Roth, K. (2000). Why Companies Go Green: A model of ecological responsiveness. Academy of Management Journal, 43(94), 717-736. http://dx.doi.org/10.2307/1556363

Chen, M. K., \& Shih, L. H. (2007). An empirical study of implementation of green supply chain practices in the electrical and electronic industry and their relation to organizational performances. International Journal of Environmental Science and Technology, 4(3), 383-394.

Chin, W. W. (1998). The partial least squares approach to structural equation modeling. In G. A. Marcoulides (Ed.), Modern Methods for Business Research Erlbaum (pp. 295-358). Mahwah.

Cho, C. H., \& Patten, D. M. (2007). The role of environmental disclosures as tools of legitimacy: a research note. Accounting, Organizations and Society, 32(7-8), 639-647. http://dx.doi.org/10.1016/j.aos.2006.09.009

Clarkson, P., Li, Y., Richardson, G. D., \& Vasvari, F. P. (2008). Revisiting the relation between environmental performance and environmental disclosure: an empirical analysis. Accounting Organizations and Society, 33(3), 303-327. http://dx.doi.org/10.1016/j.aos.2007.05.003

Davidson, W. N., \& Worrel, D. J. (2001). Regulatory pressure and environmental management infrastructure and practices. Business and Society, 40(4), 315-342. http://dx.doi.org/10.1177/000765030104000305

Department of Environment. (2012). The national policy on the environment. Retrieved from www.doe.gov.my

Despeisse, M., Ball, P. D., \& Evans, S. (2012). Modeling and tactics for sustainable manufacturing: an improvement methodology. In G. Seliger (Ed.), Sustainable Manufacturing. http://dx.doi.org/10.1007/978-3-642-27290-5_2

Fornell, C., \& Larcker, D. F. (1981). Evaluating structural equation models with unobservable and measurement error. Journal of Marketing Research, 18, 39-50. http://dx.doi.org/10.2307/3151312

Freeman, P. K. (1994). Integrating environmental risk into corporate strategy. Risk.Management, 41(7), 54-59.

Frosch, R. A., \& Gallopoulos, N. E. (1989). Strategies for Manufacturing. Scientific American, 261(3), 144-152. http://dx.doi.org/10.1038/scientificamerican0989-144

Gonzalenz-Benito, J. C., \& Gonzalenz-Benito, O. C. (2006). A review of determinant factors of environmental proactivity. Business Strategy and the Environment, 15(2), 87-102. http://dx.doi.org/10.1002/bse.450

Gutowski, T. G., Branham, M. S., Dahmus, J. B., Jones, A. J., Thiriez, A., \& Sekulic, D. P. (2009). Thermodynamic analysis of resources used in manufacturing processes. Environmental Science and Technology, 43(5), 1584-1590. http://dx.doi.org/10.1021/es8016655

Hair, J. F., Hult, G. T., Ringle, C. M., \& Sarstedt, M. (2013). A primer on partial least squares structural equation modeling (PLS-SEM). Thousand Oaks, Carlifornia: Sage Publications Ltd.

Hart, S. L. (1995). A natural resource-based view of the firm. Academy Management Revision, 20(4), 986-1014.

Hart, S., \& Ahuja, G. (1996). Does it pay to be Green? An empirical examination between emission reduction and firm performance. Business Strategy and the Environment, 5, 30-37. http://dx.doi.org/10.1002/(SICI)1099-0836(199603)5:1<30::AID-BSE38>3.0.CO;2-Q

Hartmut, K., \& Sami, K. (2006). Environmentally Sustainable Manufacturing: A Survey of Industry Practices. Proceedings of Life Cycle Engineering. 
Henri, J. F., \& Journeault, M. (2008). Environmental performance indicators: an empirical study of Canadian manufacturing firms. Journal of Environmental Management, 87, 165-176. http://dx.doi.org/10.1016/j.jenvman.2007.01.009

Holdren, J. P., \& Ehrlich, P. R. (1974). Human population and the global environment. American Scientist, 62(3), 282-292.

International Environmental Agency. (2007). International bioenergy annual report.

Jabbour, C., \& Santos, F. (2006). The evolution of environmental management within organizations: toward a common taxonomy. Environmental Quality Management, 16(2), 43-59. http://dx.doi.org/10.1002/tqem.20120

Jovane, F., Yoshikawa, H., Alting, L., Boër, C. R., Westkämper, E., Williams, D., .. Paci, A. M. (2008). The incoming global technological and industrial revolution towards competitive sustainable manufacturing. CIRP Annuals Manufacturing Technology, 57(2), 641-659. http://dx.doi.org/10.1016/j.cirp.2008.09.010

Judge, W., \& Krishman, H. (1994). An empirical investigation of the scope of firmsenterprises. Strategy, Business and Society, 33(2), 167-191. http://dx.doi.org/10.1177/000765039403300204

King \& Lenox. (2001). Exploring the locus of profitable pollution reduction. Institute of Operation Research and Management, 48(2), 289-299.

Lai, K., \& Wong, C, W. Y. (2012). Green logistics management and performance: Some empirical evidence from Chinese manufacturing exporters. Omega, 40, 267-282. http://dx.doi.org/10.1016/j.omega.2011.07.002

Leahu-Aluas, S. (2010). Sustainable manufacturing: An overview for manufacturing engineers. Retrieved from http://www.ngmanufacturingus.com/media/whitepapers/Sustainable_Manufacuring_for_Engineers.pdf

Lin, L., \& Fang, Y. (2006). The impact of mobile commerce application on corporate performance: moderate effect of market-orientation: an example of logistic related industry in Taiwan. Journal of e-Business, $8(2)$, 271-294.

Link, S., \& Naveh, E. (2006). Standardization and discretion: does the environmental standard ISO 14001 lead to performance benefits? IEEE Transaction on Engineering Management, 53, 508-519. http://dx.doi.org/10.1109/TEM.2006.883704

Lopez-Gamero, M. D., Molina-Azorin, J. F., \& Claver-Cortes, E. (2009). The whole relationship between environmental variables and firm performance: Competitive advantage and firm performance as mediator $\begin{array}{llll}\text { variables. Journal of Environmental Management, 90(10), 3110-3121. } & \text {. }\end{array}$ http://dx.doi.org/10.1016/j.jenvman.2009.05.007

Molina-Azorin, J. F., Claver-Cotes, E., Lopez-Gamero, M. D., \& Tari, J. J. (2009). Green management and financial performance: a literature review. Management Decision, 47(7), 1080-1100. http://dx.doi.org/10.1108/00251740910978313

Nishitani, K., Jannah, N., Ridwan, H., \& Kaneko, S. (2013). The influence of voluntary and mandatory environmental performance on financial performance: Empirical study of Indonesian firms. Discussion Paper Series, Kobe University. http://www.rieb.kobe-u.ac.jp/academic/ra/dp/English/DP2013-01.pdf

Nyirenda, G. (2013). Environmental management practices and firm performance in a South African mining firm. Managing Global Transitions, 11(3), 243-260.

OECD. (2009). Organization for Economic Corporation Development Annual Report.

Omar, R., \& Samuel, R. (2011). Environmental management amongst manufacturing firms in Malaysia. Proceeding of the $3^{\text {rd }}$ International Symposium \& Exhibition in Sustainable Energy and Environment, Melaka, Malaysia.

Porter, M. E., \& Van der Linde, C. (1995). Green and Competitive: Ending the Stalemate. Harvard Business.Review, 73(5), 120-134.

Rassier, D. G., \& Earnhart, D. (2010). Does the porter hypothesis explain expected futurefinancial performance? The effect of clean water regulation on chemical manufacturing firms. Environmental \& Resource Economics, 45(3), 353-377. http://dx.doi.org/10.1007/s10640-009-9318-0

Ringle, C. M., Wende, S., \& Will, A. (2005). SmartPLS 2.0. Retrieved from www.smartpls.de

Rusinko, C. A. (2007). Green manufacturing: An evaluation of environmentally sustainable manufacturing 
practices and their impact on competitive outcomes. IEEE Transactions on Engineering Management, 54(3), 445-454. http://dx.doi.org/10.1109/TEM.2007.900806

Schoenherr, T., \& Talluri, S. (2012). Environmental sustainability initiatives: a comparative analysis of plant efficiencies in Europe and the U.S. Science, 35(1), 87-108.

Sharma, S., \& Vredenburg, H. (1998). Proactive corporate environmental strategy and the development of competitively valuable organizational capabilities. Strategic Management Journal, 19(8), 729-753. http://dx.doi.org/10.1002/(SICI)1097-0266(199808)19:8<729::AID-SMJ967>3.0.CO;2-4

Siedel, R., Shahbazpour, M., \& Seidel, M. (2007). Establishing sustainable manufacturing practices in SMEs. Retrieved

from https://www.google.com.pk/search?q=Establishing+sustainable+manufacturing+practices+in+SMEs

Tenenhaus, M., Vinzi, V. E., Chatelin, Y. M., \& Lauro, C. (2005). PLS path modeling. Computational Statistics \& Data Analysis, 48(1), 159-205. http://dx.doi.org/10.1016/j.csda.2004.03.005

Tooru, S. (2001). Certification and operational performance of ISO14001. KamipaGikyoshi, 55(1), 52-58.

UNEP. (2007). United Nations Environmental Programme annual report.

Vijayaraghavan, A. (2010). The social responsibility of business in natural resources protection. Retrieved from http://www.triplepundit.com/2012/09/social-responsibility-business natural-resource-protection

Wagner, M. (2005). How to reconcile environmental and economic performance to improve corporate sustainability: corporate environmental strategies in the European paper industry. Journal of Environmental Management, 76, 105-118. http://dx.doi.org/10.1016/j.jenvman.2004.11.021

Walley, N., \& Whitehead, B. (1994). It's not easy being green. Harvard Business Review, 72(3), 46-52.

Watson, K., Klingenberg, B., Polito, T., \& Geurts, T. (2004). Impacts of environmental management systems implementation on financial performance. Management of Environmental Quality, 15, 622-628. http://dx.doi.org/10.1108/14777830410560700

Wetzels, M., Odekerken-Schrder, G., \& Van Oppen, C. (2009). Using PLS path modeling forassessing hierarchical construct models: guidelines and empirical illustration. MIS Quarterly, 33(1), 177-195.

Wong, Y. C., Wong, K. Y., \& Ali, A. (2009). A Study on Lean Manufacturing Implementation in the Malaysian Electrical and Electronics Industry. European Journal of Scientific Research, 38(4), 521-535.

Zhu, Q., \& Sarkis, J. (2004). Relationships between operational practices and performance among early adopters of green supply chain management practices in Chinese manufacturing enterprises. International Journal of Operations Management, 22, 265-289. http://dx.doi.org/10.1016/j.jom.2004.01.005

\section{Copyrights}

Copyright for this article is retained by the author(s), with first publication rights granted to the journal.

This is an open-access article distributed under the terms and conditions of the Creative Commons Attribution license (http://creativecommons.org/licenses/by/3.0/). 